\title{
Toward Better Access to Health Insurance Coverage for U.S. Retirees in Mexico
}

\author{
D avid C. W arner, Ph.D., ${ }^{(1)}$ Lauren R. Jahnke, M.P.Aff. ${ }^{(2)}$
}

\section{Warner DC, Jahnke LR. Toward Better Access to Health Insurance Coverage for U.S. Retirees in Mexico. Salud Publica Mex 2001;43:59-66. The English version of this paper}

is available at: http://www.insp.mx/salud/index.html

\begin{abstract}
A bstract
Many retirees from the United States of America have limited health insurance coverage while living in Mexico. Medicare and Medicaid benefits are not portable to other countries and Medigap (private insurance that supplements Medicare) is very limited. This causes economic and medical hardships and serves as a barrier to retirement to $\mathrm{Me}-$ xico. Increasing numbers of U.S. retirees will be interested in moving to Mexico in the future because of the climate, the culture, and the lower cost of living. The numbers are increasing as a result of several factors such as aging "baby boomers" and the rapidly growing Mexican-origin population in the U.S.A. who are citizens or permanent residents but would like to return to their communities of origin after working in the U.S.A. There are several policy initiatives that could provide opportunities for improving health insurance coverage for these retirees that could be cost-effective. The full version of this paper is available to 0 at: http:/ /www.insp.mx/salud/index.html
\end{abstract}

Key words: insurance, health; retirement; health services cover age; cost-benefit analysis; M exico

\author{
Warner DC, Jahnke LR. \\ Mejor accesibilidad a los seguros de salud \\ para jubilados estadunidenses residentes en México. \\ Salud Publica Mex 2001;43:59-66. \\ El texto completo en inglés de este artículo está \\ disponible en: http://www.insp.mx/salud/index.html
}

\section{Resumen}

Muchos jubilados estadunidenses cuentan con una co bertura de seguro médico restringida mientras viven en México. Los beneficios de Medicare y Medicaid no son transferibles a otros países, y el Medigap (el seguro privado que complementa a Medicare) es muy limitado. Esto genera privaciones económicas y médicas y es una barrera para el retiro en México. Un número creciente de jubilados estadunidenses estaría interesado en mudarse a México en el futuro, debido al clima, la cultura y el costo más bajo de la vida. Este número creciente es resultado de varios factores: el envejecimiento de los baby boomers y la creciente población de origen mexicano con ciudadanía estadunidense 0 con residencia permanente, a la que le gustaría regresar a su comunidad de origen después de haber trabajado en Estados Unidos de América. En este trabajo se presentan diversas iniciativas que podrían ofrecer oportunidades para mejorar la cobertura de seguro médico para los retirados y que, además, podrían ser costo-efectivas. El texto completo de este artículo también está disponible en: http:// www.insp.mx/salud/index.html

Palabras clave: seguro de salud; jubilación; co bertura de servicios de salud; análisis de costo-beneficio; México

This paper was originally prepared under contract to Healthcare Redesign International, which was supported by the California HealthC are Foundation as part of the Cross Border Health Insurance Initiative. The Cross Border H ealth Insurance Initiative is a project of the California $\mathrm{H}$ ealthC are Foundation and is being conducted in collaboration with the Fundación Mexicana para la Salud, the Academy for International Health Studies, and Healthcare Redesign International. This paper was presented, in a somewhat different form, at a meeting of the Cross Border Health Insurance Initiative in Cuernavaca, Mor., Mexico, on June 3, 1999.

(1) Lyndon B. Johnson School of Public Affairs, The U niversity of Texas at A ustin. Austin, Texas, United States of America (U.S.A.).

(2) LRJ Research \& Consulting. Austin, Texas, U.S.A.

Received on: September 4, 2000 - Accepted: September 18, 2000

Reprint requests to: Dr. D avid W arner. LB] School of Public Affairs, The University of Texas at Austin.

D rawer Y, University Station. Austin, Texas, U.S.A. 78713-8925.

E-mail: david.warner@ mail.utexas.edu 
$\mathrm{M}$ edicare and Medicaid offer a significant safety net to most elderly and disabled people in the United States of America (U.S.A.). Medicare is a uniform national program consisting of two parts: Part A, hospital insurance, and Part B, Supplementary Medical Insurance. People become eligible for Part A at retirement if they are at least 65 and if they or their spouse have worked for ten years in employment where at least a minimum sum was contributed to Social Security. Part A covers inpatient hospital care, a limited amount of skilled care in a nursing home, home health care, and hospice care. The rates for these services are set prospectively depending upon a number of factors. There is an inpatient hospital deductible of US\$768 in 1999. Part A is funded from a trust fund that is financed by employee and employer contributions that add up to 2.9 percent of virtually all wages paid in the U.S.A.

Part $B$, on the other hand, is not tied to the Social Security trust fund. Part B is available to almost all resident citizens, permanent residents age 65 and above, and younger disabled persons who are receiving Part A coverage who pay a premium for Part B. Part B covers physician services in the hospital and in the doctor's office. It also covers clinical lab tests, durable medical equipment, diagnostic tests, ambulance services, and a number of other services and therapies. For these services, Medicare pays 80 percent of the approved Medicare rate and the beneficiaries pay 20 percent. The premium for Part B in 1999 is US $\$ 45.50$ per month and is scheduled to increase in years to come. An annual deductible of US\$100 must be met before Part B benefits become available. Beneficiaries with more income often supplement Medicare coverage with a health plan provided by a former employer or through private insurance called Medigap.

In 1998, total expenditures for Medicare were more than US $\$ 200$ billion to care for over 35 million elderly and disabled beneficiaries. The rapid growth in cost and significant gaps in coverage have sparked initiatives for reform such as the Balanced Budget Act of 1997 and the National Bipartisan Commission on the Future of Medicare (which was supposed to make recommendations for reform by March 1999 but was unable to come to consensus).

Medicaid provides care for the low-income disabled and low-income elderly who might not be eligible for Medicare. It also provides coverage for coinsurance and deductibles for low-income Medicare beneficiaries. Unlike Medicare, which has national standards regarding eligibility, benefits, and conditions of participation for providers, Medicaid is a state program that is subject to federally mandated basic benefits and eligible groups, but which gives the individual states the option to extend coverage to additional groups and to offer expanded benefits. The states administer the program but receive federal matching funds that range from 50 percent to almost 80 percent of the allowable costs. In addition to the full range of hospital and outpatient services, Medicaid provides coverage for services such as outpatient pharmaceuticals and long-term nursing home care not covered by Medicare.

Medicaid is the primary funder of long-term care in the USA. Medicaid expenditures for long-term care have grown from $\$ 21.1$ billion in fiscal 1987 to $\$ 56.1$ billion in fiscal 1997. ${ }^{1}$ These funds provide care for the elderly and also the mentally and physically challenged. Traditionally, nursing home care has consumed the largest share of the Medicaid long-term care benefit. More recently, there has also been rapid growth in payments to Home Health Care and to Personal Care and Home and Community-Based Care programs (which are optional to the states) that provide a wider package of services in the home. These programs permit states to target certain groups and increase income eligibility levels.

To be eligible for the Medicaid long-term care benefits the individual has to meet criteria related to medical, physical, or mental dependency; have an income that in most states does not exceed up to about 2.5 times the poverty level, and have no assets other than a home up to a certain value, an automobile, and personal possessions. If the person has a spouse, then the spouse is allowed to retain from US\$15 348 to $\$ 76740$ in assets depending on the state. The spouse is also able to retain his or her own income and/or an allowance of US\$1 295 to US\$1 919.50 per month (in 1996) of joint income for living expenses. ${ }^{2}$

Many retirees from the United States who choose to live in Mexico have limited health insurance coverage unless they return to the U.S.A. Except in very limited circumstances on the Mexican and Canadian borders and en route to Alaska, Medicare does not pay for services received outside the United States. ${ }^{3} \mathrm{Me}-$ digap insurance is limited to covering emergency services used during travel or a temporary stay of less than 60 days abroad. ${ }^{4}$ Private health insurance in Mexico is very difficult to obtain for persons older than 65. This lack of coverage serves as a disincentive to retire to Mexico. Many who do retire in Mexico return to the U.S.A. sooner than they had planned, often with advanced health problems. Although they receive no coverage in Mexico, Medicare beneficiaries must continue to contribute $\$ 45.50$ a month (1999 amount) to retain their Part B coverage. For every year they fail to contribute these funds after age 65 , their annual 
premium increases by 10 percent should they choose to join later.

Medical services in general are significantly less expensive in Mexico. Many persons choose to retire in Mexico for cost, climate, cultural, and family reasons. Some argue that the lack of adequate health coverage in Mexico may lead some who would otherwise retire in Mexico to remain in the USA and become dependant on its public social welfare system.

\section{People Affected}

There appear to be at least three different groups of U.S. citizens and permanent residents who retire to Mexico for somewhat related reasons. a) Middle income and above retirees of non-Mexican origin: There are an estimated 75000 to 100000 people in this group. b) Lower-middle to lower income retirees of non-Mexican origin: There are an estimated 75000 to 100000 people in this group and they often live in the same locations as the middle and high income retirees, i.e., coastal communities and larger cities. c) Mexican-origin U.S. retirees entitled to Social Security and Medicare: Estimates for this group are also 75000 to 100000 people and they may live in the locations mentioned, but also may return to their states and communities of origin.

The group of people who have middle class and above incomes in retirement often choose to retire to Mexico for the ability to live an even more satisfying and interesting lifestyle. They may retire to locations such as Lago de Chapala, Guadalajara, Cuernavaca, San Miguel de Allende, Oaxaca, Baja California Sur, or Ensenada, and live comfortably with other Americans and Canadians in an enclave. This category includes people who live part of the year in the U.S.A. and part of the year in Mexico, and also those who live permanently in Mexico. Most of these retirees would lead middle class lives in the U.S.A., if less interesting ones and with less household help than they have in Mexico. Availability of high quality medical coverage could be attractive to this population to encourage new retirement developments. Although there are excellent hospitals and physicians in the private sector in many of the locations where this group tends to retire, there are limited resources in others. More comprehensive coverage could help finance the development of higher quality private health services.

A comparably sized group with lower incomes also tends to live in some of the centers mentioned above, but in generally less affluent circumstances. Low-cost trailer parks abound in northern Baja near Ensenada and Rosarito and a significant number of people live on the west side of Guadalajara or in Oaxaca on incomes of US\$500 to $\$ 600$ a month. In a nonrandom survey of retirees in San Miguel, Guadalajara, Chapala, Rosarito, and Ensenada conducted by graduate students from the Lyndon B. Johnson School of Public Affairs at The University of Texas at Austin, we found that while 74.8 percent of the people who responded had an FM-3 or an FM-2 visa, 21 percent lived on less that US\$15 000 a year and another 27 percent had incomes between US\$15 000 and $\$ 25000 .^{5,6}$ It is very difficult to know the total number in the low income category, but it is important to note that these persons stay independent and are not a burden to the public social services systems of either country.

A third group -probably the largest now and certainly the largest in the future- is persons who were born and raised in Mexico who are citizens or permanent residents of the U.S.A. and who choose to return to Mexico to retire. It is difficult to estimate the numbers in this group because they often return to their previous home towns or nearby, where they may have maintained ownership of or inherited housing, and as Mexican natives they may not require visas to live in Mexico. It will become even more complex to estimate the total numbers and identify where they live as increasing numbers seek citizenship in the US since they can also now retain their Mexican citizenship. In 1997, there were an estimated 285000 Mexican-born residents over the age of 65 living in the US, of whom 197000 were not U.S. citizens. ${ }^{7}$ This figure does not include those who had already retired to Mexico and are citizens of the U.S. or permanent residents. In projecting into the future, the number of persons of Hispanic origin in the four US border states is expected to grow from 15.9 million in 1995 to 34.7 million in $2025 .{ }^{8}$ More immediately, the number of persons above the age of 65 of Hispanic origin in Texas and California alone is projected to increase from 542179 in 1990 to 1279060 in 2010.,'10 Many of these persons have family ties in Mexico and might find it a very attractive place to retire-especially if health coverage were available.

All of these groups, except those few with excellent private coverage, are affected by the lack of available health coverage. Those who choose to retain their Medicare Part B benefits contribute US $\$ 45.50$ per month and incur substantial costs in cash payments for care in Mexico. They also incur significant costs for the more expensive treatments and diagnostics because they must travel to the U.S.A. to use their Medicare entitlement. These elderly often receive sporadic care for their chronic illnesses in Mexico, and return to the U.S.A. to receive costly hospital care and treat- 
ments that might have been avoided or mitigated through better continuity of health coverage. Many who would prefer to retire to Mexico or to remain there are precluded from doing so because of their concern that they might become ill and not be able to afford the illness. U.S. military retirees have their care covered by Tricare in Mexico (the successor to the CHAMPUS program) until they turn 65 , at which time their coverage converts to Medicare and they have no coverage if they are not living in the U.S.A.

Similarly, couples or individuals who retire to Mexico might wish to remain even after one or both of the retirees needs skilled help to remain independent at home. Because of the cost of these services, even in Mexico, they decide instead to return to the U.S.A. where one or both of them must ultimately move into a nursing home, an assisted living facility, or receive extensive and costly care at home. Medicaid and Medicare pay for these services at very high rates.

\section{Additional Stakeholders}

There are a number of potential stakeholders to be considered when reviewing the options of Medicare portability, developing a Medicaid waiver, and increasing the availability of private health insurance for U.S. retirees in Mexico. Following are some of these stakeholders and their perspectives and interests, not including retirees and potential retirees, which are discussed above.

U.S. employers who have funded retirement health benefits (e.g., federal, state, and local government retirees; large private employers, and union-administered health benefit plans). Since Medicare does not cover services in Mexico, U.S. retirees with this coverage may cost their former employers more than they would have if they had remained in the U.S.A. With even partial Medicare coverage in Mexico, these beneficiaries might be less costly than U.S. retirees since pharmaceuticals and dental care are much less expensive in Mexico. US medical and hospital interests. As the coverage is for retirees who are more or less permanently living in Mexico, there would probably not be much opposition from these groups (comprehensive coverage might affect some referral hospitals in the U.S. and some border state specialists).

U.S. Health Care Financing Administration (HCFA). HCFA must consider the impact of opening the door to payment abroad for Medicare and the federalized option for long-term care abroad.
American Citizens Abroad (ACA). Medicare coverage abroad is one of their top issues; ACA is headquartered in Geneva but is supportive of a waiver research and demonstration project in Mexico.

American Association of Retired Persons (AARP). AARP does not have a position currently. These proposals expand choice for retired persons, but they constitute a departure from the core Medicare program that AARP is trying to save.

Employers in Mexico. Would probably welcome the enhanced private sector health care system and improved accountability systems developed by health plans, doctors, and hospitals; however, higher prices could be a result.

Mexican Government. Increased demand in the private sector will utilize some of the surplus physicians. However, it would not like to see the best specialists and physicians with substantial experience and training leave IMSS (Mexican Institute of Social Security) and ISSSTE (Institute of Social Security and Services for State Workers). Increased economic activity and foreign exchange brought by the increase in retirees would be welcomed.

U.S. politicians. This does not seem to be a significant issue for local politicians except perhaps in Arizona and San Diego, California. Few U.S. Congresspersons have much of a stake in this except those with a large number of Mexican-origin constituents. A presidential candidate might find it more attractive to support a research and demonstration project: a waiver research and demonstration project is unlikely to offend many while pleasing a million or so eligible voters living outside the U.S.A.

IMSS and ISSSTE physicians and workers. May have some concern over the growth of the private sector. However, this is mitigated by the additional employment opportunities.

Sellers of Medigap policies. Would need to change some terms of their policies but it should not be a major problem.

U.S. health plans, their Mexican subsidiaries, and tertiary hospitals and medical schools in the U.S.A. U.S. health plans should see this as an opportunity, as should Mexican health plans. U.S. referral hospitals are already establishing outposts and relationships in Mexico in the short term to get referrals and in the longer term to develop a binational delivery system.

Privatehospitals, physicians, and peer review organizations in Mexico. High quality providers should be very supportive since it will increase demand for their services; they may find that certification and documentation 
requirements will be challenging, but they should be eager to undertake it.

U.S. Nursing home and assisted living interests. They could become approved vendors of some services abroad.

\section{Policy Significance and Financial Impact}

Over the next 30 years the U.S.A. must continue to adapt to a world economy, further the process of integration of the nations of North America, and find equitable ways to reduce the high cost of a growing aging population. Similarly, Mexico must find ways to increase its exports, find employment for a rapidly growing labor force, finance medical care that is modern and adequate for a growing and increasingly aging population, and build an infrastructure of hospitals and clinics that can accommodate this population. Expanding health coverage to elderly U.S. retirees in Mexico has the promise to help each nation address these issues.

Medicare portability is one way to address this issue. It will be important for U.S. policy makers to understand the implications of this portability in terms of cost, quality, and program integrity. Mexican decision-makers may want to examine the impact on prices and services, especially in the public sector, if such funding were available. In the U.S.A., there might also be a parallel concern regarding the long-term precedent if such coverage were extended to all Americans living abroad. Although mandatory open contracting of government health and social welfare programs is exempted from the general free trade requirements of the North American Free Trade Agreement (NAFTA), this would appear to be an area worthy of study. ${ }^{11}$ The special relationships under NAFTA between the U.S.A. and Mexico justify the consideration of these options.

If the option of portability of Medicare or Medicaid is considered, the principal financial impact to the U.S.A. would be the increased or decreased cost to the Medicare program (and the Medicaid program if the modified long-term care benefit were included). The macro economic impact (e.g., the employment impact of additional people choosing to retire abroad) would also need to be considered. At the same time, lower social services costs might offset the increased obligation of covering care in Mexico since many people who would otherwise become dependent on government programs and their relatives in the U.S. could be self-sufficient. One calculation of the impact is presented below. If the average beneficiary uses an additional US\$1 000 in medical services in Mexico annually, then there is a net gain in US\$100 million of export income for every 100000 such persons in Mexico to the Mexican health economy and a loss of a comparable amount to the U.S. economy. On the other side of the ledger, if US $\$ 1000$ in Medicare expenditures in Mexico replace US\$2 000 in expenditures in the U.S., then the taxpayers in the US are saving up to US $\$ 100$ million in payments. To the extent the Medicare funds replace funds the individual formerly paid out-ofpocket, then the taxpayers are paying more. Since the average Medicare beneficiary currently costs the program about US $\$ 6000^{12}$ these estimates are quite conservative. Since this level of expenditure is projected to increase to US $\$ 14000$ per capita by 2020 (equaling all other consumption of goods and services by the elderly) the need to seek cost-effective solutions is clear. ${ }^{13}$

From the Mexican perspective, an additional US\$100 million or more a year into the private health sector would, on the margin, make investment in private hospitals and clinics in many areas more feasible. It could also mean that major retirement properties would be more viable if reimbursement and high quality medical facilities were available, attracting more retirees. An increase of 100000 U.S. retirees a year, each spending on average US\$10 000 on goods and services, would amount to an additional $\$ 1$ billion in foreign exchange. This would increase Mexico's ability to increase the purchase of other goods and services from the U.S.A. and elsewhere. From the U.S. perspective, many of the services purchased in Mexico could replace lower-wage workers in the U.S.A. and might create jobs in Mexico for those who might otherwise be likely to relocate to the U.S.A. to find employment.

\section{Potential Solutions/Innovations}

Although, in principle, the United States Congress could decide to make Medicare benefits portable to Mexico by amending Title XVIII of the Social Security Act, they would be reluctant to do so without first investigating the feasibility and cost of such an action. Consequently, we will look at several options for waivers for a Medicare research and demonstration project to extend Medicare in some form to selected beneficiaries in Mexico. Other potential solutions that will be discussed are the possibility of using Medicare Medical Savings Accounts for retirees in Mexico, the possibilities of modifying Medicaid coverage for long-term care services received in Mexico, and some approaches to improving private health insurance for persons above 65 living in Mexico. 
Structuring a research and demonstration waiver for medicare portability

Medicare waivers are generally justified if they extend access or improve quality of care for vulnerable populations at no additional cost to the program. It may be worthwhile to develop research and demonstration waiver(s) under Medicare to examine the impact of some kind of portability of Medicare to Mexico. Further, an evaluation of limited portability of a variant of the Medicaid long-term care benefit could be supported. Similarly, private insurers might develop a better supplemental benefit for Medigap coverage abroad for extended periods if Medicare paid for some of the coverage. Finally, retirees might receive credit against at least part of their Part B obligation for payment for insurance (IMSS or otherwise) that covers these services while they live in Mexico.

Since payment for services in Mexico is not permitted under Medicare except on the border in very restrictive circumstances, the U.S. Congress would have to include in an appropriations bill a note that authorized the United States Health Care Financing Administration (HCFA) to engage in such a research and demonstration project, and also appropriate sufficient funds to conduct the experiment. The note would have to permit HCFA to waive certain conditions of participation such as requirements for physicians to be licensed to practice in the United States or for hospitals to be certified by the Joint Commission on Accreditation of Health Organizations (JCAHO) and meet certain physical code requirements. Further, since for most Part B services HCFA relies on state certification of labs, physician qualifications, blood products, etc., there would have to be a waiver to permit some level of local certification of these providers and facilities. It might also be possible for some of the providers in Mexico to enter into a professional relationship with one or more clinics or hospitals in the U.S.A. in terms of specialty consults or certification of processes. Coverage of telemedicine consults with providers in the U.S.A. could be an additional area that might be examined.

\section{Allocating part of the Part B premiums to buying coverage for services in Mexico}

A more modest change might be to allow retirees in Mexico to substitute half of their Part B premiums with payments to IMSS or a private health insurance scheme which covers Part B-like services, such as ambulatory care, in Mexico. This could be done as a demonstration project or even as a change in policy. It would tend to encourage enrollment in Part B while having substantial offsetting savings to the Medicare program since Part B premiums cover less than 25 percent of the current costs of the program. This would be administratively easy to implement since the beneficiary could file a proof of payment of both Part B and Mexican coverage with his/her income tax filing and receive a credit for up to one-half of the Part B premiums. An evaluation of the impact of this option would be difficult since it would require having access to U.S. Internal Review Service (IRS) information.

\section{Permitting a medicare medical savings account for retirees} living in Mexico

The Balanced Budget Act of 1997 created the possibility of establishing Medical Savings Accounts (MSAs) under Medicare whereby beneficiaries can use Medicare to buy an insurance policy covering all Medicare benefits above a high deductible ranging up to US\$6 000. In this arrangement, HCFA deposits the difference between the Average Per Capita Cost for that person under Medicare capitation rates and the premium for the insurance purchased into a "medical savings account which can pay for any medical expenses." The rules, however, provide that "an individual is not eligible to enroll (or continue enrollment) in an MSA plan for a year unless the individual provides assurances satisfactory to the Secretary that the individual will reside in the U.S.A. for at least 183 days during the year." ${ }^{\prime 14}$ Making selected residents in Mexico eligible for Medical Savings Accounts would be in the spirit of the demonstrations proposed in the Balanced Budget Act, even if in conflict with the language. Given prices for pharmaceuticals and routine office visits in Mexico, it is quite likely that many retirees in Mexico would accumulate funds in their savings accounts over time. As with the Medicare waiver discussed above, Congress might have to authorize and possibly appropriate funds for a waiver demonstration project for Medical Savings Accounts for those retirees living in Mexico for over half of the year. To control costs, HCFA might only deposit 70 or 80 percent of what the person would be entitled to under the program if he or she lived in the U.S.A. This could have a substantial positive financial impact on the Medicare Program.

\section{A federalized long-term care benefit for retirees in Mexico}

Medicaid expenses for long-term care have grown rapidly and the projected impact of the baby boomers in 20 years will exacerbate this problem. One of the policies recommended to mitigate the financial impact to 
Medicaid is to subsidize the purchase of long-term care insurance, which federal tax law already allows, and some states such as Connecticut further promote by relaxing the asset limits one is allowed to keep if they meet eligibility requirements after exhausting their long-term care coverage. Some other recommendations are to promote out-of-facility programs, to provide funds to family members who serve as caretakers (proposed in former president Bill Clinton's 1999 State of the Union address), and to develop programs where the clients themselves are given a budget that they use to buy and hire the goods and services that they require.

Another option is to make the Medicaid long-term care benefit partially portable. This might be accomplished by the federal government adding this benefit in addition to the Medicare home health benefit covered for those who are in a waiver project. Retirees in Mexico could receive US $\$ 10$ to $\$ 20$ a day, for example, if they meet income and dependency eligibility criteria from their home state or meet a federal standard and live in Mexico. In this program, retirees would receive only federal funds, amounting to only 20 to 30 percent of the federal obligation for the average person in a nursing home in the U.S.A. States would save considerably since they would not be obligated to pay anything. Of course, as with any demonstration project, there would have to be mechanisms put in place to assure quality and avoid fraud. Direct funding to the individual or his or her guardian or spouse would be a possible course of action to help mitigate the administrative burden to the Medicaid program.

Approaches for developing improved private insurance coverage for retirees in Mexico

Currently retirees in Mexico have limited options for purchasing private health insurance. Private companies in Mexico usually exclude pre-existing conditions. One major Mexican insurance company contacted indicated that it does not sell health insurance policies to persons 64 and older; however, if the policy was purchased before age 64 , it can continue to be renewed indefinitely. Eight of the ten standard Medigap insurance plans available to retirees cover foreign travel emergencies, paying 80 percent of charges for emergency care received in a foreign country during the first 60 days of a trip outside the U.S.A. Persons residing permanently in Mexico are not covered by Medigap. Some plans may have evacuation insurance, but no coverage if care is required in Mexico. One approach is to develop a product, either in the U.S.A. or Mexico, that covers major medical expenses for conditions needing treatment in Mexico for those who are retired there. This coverage could supplement existing Medicare and Medigap coverage. The presumption is that the individual could afford to pay for ambulatory care on an out-of-pocket basis and would go to the U.S. for further care in non-emergency situations.

Another option is for existing plans to develop new partially portable Medicare supplementary benefits. As growing numbers of Americans retire to Mexico and as U.S. hospitals build their relationships with providers in leading retirement areas, new partially managed care options may become feasible.

\section{Conclusions}

The lack of portable health insurance for retirees in Mexico makes the decision to retire there a riskier decision than it should be. And, the lack of stable sources of private funds for health care is one reason given why many retirement communities are not developed in Mexico. Since the incentives to retire to Mexico will continue to grow, it would appear prudent for the U.S. government to explore some of the options detailed above.

\section{References}

1. American Association of Retired Persons Public Policy Institute. Trends in Medicaid long term care spending (D ata Digest). W ashington, D.C.: AARP, 1998.

2. U.S. Health Care Financing Administration. Spousal impoverishment. Available online at http://www.hcfa.gov/medicaid/obs10.htm.

3. U.S. Social Security Act, Title XVIII. Section 1814, Conditions of and limitations on payments for services. Available online at http://www.ssa.gov/ O P_Home/ssact/title18/1814.htm.

4. Health Care Financing Administration. 1999 Guide to health insurance for people with Medicare. Available online at http://www.medicare.gov/ publications/guide.pdf. p. 14.

5. Lyndon B. Johnson School of Public Affairs, The University of Texas at Austin. Getting what you paid for: extending Medicare to eligible beneficiaries in Mexico. Austin (TX): The University of Texas, 1999;US-Mexican Policy Report N 0. 9.

6. Lyndon B. Johnson School of Public Affairs, The University of Texas at Austin. Medicare benefits for recipients living in Mexico: Proceedings of a conference. Austin (TX):The University of Texas,1999;US-Mexican Policy Studies Program, 0 ccasional Paper N 0. 8.

7. U.S. Bureau of the Census, March 1997 CPS. Table 10.12, Foreign-born and citizenship by race and ethnicity age 65 and over: both sexes. Available online at http://www.census.gov/population/www/socdemo/ foreign.html. Internet release date: August 1998.

8. U.S. Bureau of the Census. Projected state populations by sex, race, and hispanic origin: 1995-2025. Available online at http://www.census.gov/population/projections/state/stpjrace.txt.

9. Texas State Data Center. Texas Population Estimates and Projections Program, D epartment of Rural Sociology, Texas A\&M U niversity. Final pro- 
jections of the population by age group, sex, and race/ethnicity and migration scenario for 1990, 2000, and 2010 for the state of Texas. College Station (TX): Texas State Data Center, 1996.

10. State of $C$ alifornia, D epartment of Finance. C ounty population projections with age, sex and race/ethnic detail, 1990-2040. Available online at http://www.dof.ca.gov/html/demograp/Proj_age.htm. Sacramento (CA): State of California, 1998.

11. Lyndon B. Johnson School of Public Affairs, The University of Texas at Austin. NAFTA and trade in medical services between the U.S. and Mexico. U.S.-Mexican Policy Report N 0. 7. Austin (TX), 1997.
12. McC lellan, M, Skinner, J. Medicare reform: who pays and who benefits? Health Aff 1999;18:48-62.

13. Fuchs, V. Provide, Provide: The Economics of A ging. In: Saving, T, Rattenmaier, A, eds, Medicare reform: issues and answers. Chicago: University of Chicago Press. In Press.

14. U.S. Social Security Act, Title XVIII. Section 1859, D efinitions; miscellaneous provisions. Available online at http://www.ssa.gov/O P_Home/ssact/ title18/1859.htm. 